\title{
Crisis del espacio público y estetización de la política: hacia una nueva democracia audiovisual
}

\author{
Crisis of Public Space and 'Aesthetization' of Politics: \\ Towards a New Audio-visual Democracy
}

\section{Francisca Babul}

Universidad Adolfo lbáñez

franciscababul@yahoo.com

\section{Resumen}

En la segunda mitad del siglo XIX, una serie de factores precipitan la decadencia del espacio público burgués transformando al "público" en "consumidor".

Ante la inexistencia de ideologías fuertes y la instauración de claves de lectura centradas en lo estético, las instituciones políticas han optado hoy por especializarse en los medios de comunicación. Surge, así, una forma diferente de hacer política, donde el protagonista es el nuevo espacio público: la televisión.

Asistimos, entonces, a un proceso de "personalización” y "estetización” de la política, pues en vez de una ideología se nos ofrecen personajes estéticamente atractivos. De este modo, se disuelve lo político en sus términos argumentativos, y elementos como vida privada y carisma adquieren un peso inusitado en la construcción de la imagen pública de los candidatos.

La televisión se ha instalado como un ingrediente fundamental del escenario político, reconfigurándolo según las reglas del espectáculo. Y no sólo cambia la forma en que la política se transmite, sino también el modo en que se practica. El desafío para la teoría de la comunicación radica, entonces, en investigar las potencialidades del nuevo contexto en aras de construir una sociedad cada vez más democrática.

Palabras clave: público/privado, significado/significante, audiencia, espectáculo, videopolítica, televisión, sociedad de medios, populismo.

\footnotetext{
Abstract

In the second half of the XIX century several events rushed the downfall of the "illustrated" public space transforming "the public" into consumers.

With the lack of strong ideologies and the founding of reading codes centered in aesthetic aspects, the political institutions have decided, nowadays, to specialize in mass media. Thus, a different way
} 
of making politics suddenly rises up where the leading role is played by a new public space: the television.

We are, then, before a process of "personalization" and "aesthetification" of politics because, instead of an ideology, we are offered aesthetically attractive characters. In this fashion, politics, in its argumentative terms, is dissolved, and elements like private life and charisma acquire an unusual role in the making of the public images of the political candidates.

Television has installed itself as a fundamental ingredient of the political scenario, rearranging it according to the show business style. Not only the way in which politics is transmitted changes but also the way in which it is practiced. The challenge for the theory of communication rests, then, in investigating the potentialities of this new context in such a way as to build a more democratic society.

Keywords: private/public, significant/meaning, audience, spectacle, video-politics, television, media society, populism.

\section{Introducción}

Se les ofreció la elección de convertirse en reyes o mensajeros de los reyes. Tal como los niños, quisieron todos ser mensajeros. Por eso es que sólo hay mensajeros; corren por el mundo y, como no hay reyes, se gritan entre sí los anuncios sin sentido. Gustosamente pondrían fin a sus vidas miserables, pero no se atreven, por el voto de fidelidad. Franz Kafka

La voluntad de crear espacios de debate (a saber, "espacios públicos") donde confluyan las opiniones de gobernantes y gobernados ha marcado -desde siempre- la evolución histórica de las democracias. No obstante, dichos espacios han comprendido distintas concepciones según la época en que se definan.

Estas diferencias están determinadas, a su vez, por la evolución de los términos público y privado. Si bien podemos identificar varios modelos que explicarían la compleja relación entre ambos, hay dos referencias canónicas que han logrado consagrarse en la tradición Occidental: el "modelo griego" y el "modelo burgués". Aunque hoy, ciertamente, dependamos de otras categorías, la importancia de estos patrones es clave a la hora de entender las circunstancias que caracterizan nuestra sociedad actual.

En el modelo griego o helénico se pueden distinguir con claridad las esferas de lo público y lo privado. Aquí, lo privado corresponde al ámbito de la necesidad, de la subsistencia, de la casa y la transitoriedad. Lo público, en cambio, atañe al plano de la política, donde sólo participan los hombres libres, es decir, los jefes de hogar u oikodéspotas 
(dueños de tierras o poseedores de bienes o esclavos). Hacer política es, entonces -según este modelo-, hablar, discursear, pero dejando de lado lo que ocurre dentro de la casa pues, bajo sus parámetros, la necesidad y lo económico no tienen relación alguna con lo que se discute en el terreno de lo público.

La segunda referencia canónica, en tanto, corresponde al modelo burgués ${ }^{1}$ que conlleva la Modernidad. Bajo estos parámetros, se mantiene una distancia prudente entre los campos abarcados por lo público y lo privado y, aunque ambos términos se vieron enfrentados a diversos conflictos, la sociedad ilustrada -como acentúa Richard Sennettrehusó preferir uno sobre otro, "manteniendo a los dos en estado de equilibrio" (Sennett, 1978, p. 29).

A juicio de Sennett, tanto en conducta como en creencia, los habitantes de las capitales del siglo XVIII intentaron definir lo que era y no la vida pública. En este contexto, la línea que dividía ambos imperios "era aquella sobre la cual los reclamos de la civilidad, compendiados por la conducta pública, estaban equilibrados con los de la naturaleza, compendiados por la familia" (Sennett, 1978).

A mediados del siglo XVIII comportarse "con los extraños de una manera emocionalmente satisfactoria y permanecer, sin embargo, apartado de ellos fue visto como el medio por el cual el animal humano se transformó en ser social” (Sennett, 1978, p. 29). Como consecuencia, "las capacidades para la paternidad y la amistad profunda fueron consideradas como potencialidades naturales más que como creaciones humanas" (Sennett, 1978, p29). Así, mientras el hombre se hacía a sí mismo en público, realizaba su naturaleza en el dominio de lo privado.

Sin embargo, con el tiempo se fue ampliando la significación de la esfera privada y, además de abarcar los derechos de la naturaleza dentro del núcleo familiar, comenzó a implicar aspectos internos referidos a la opinión y las creencias. Según el filósofo francés Jean-Marc Ferry:

La necesidad de mantener una cohesión social pudo justificar la institución típicamente moderna de una esfera privada de la opinión y la creencia: la conciencia individual debe ser, por así decir, privatizada, en calidad de fuero interno, mientras que el dominio público, ideológicamente neutro, está dirigido por una 'razón' nueva, distinta de la 'opinión': la razón de Estado. (1998, p. 15)

Precisamente, a juicio de la filósofa alemana Hannah Arendt, es en la irrupción de aquella esfera social en los inicios de la Edad Moderna -que rigurosamente no es ni pública ni privada- donde debemos sentar las bases de la imbricación de los términos público y

\footnotetext{
${ }^{1}$ El modelo burgués o ilustrado fue ampliamente analizado y descrito en varios de sus textos por el filósofo alemán Jürgen Habermas, entre los cuales destaca Historia y Crítica de la Opinión Pública (1962).
} 
privado. En su emblemático texto, La condición humana, Arendt enfatiza la necesidad de señalar la diferencia genealógica entre el término primigenio de lo público en la polis griega y su significado en la Modernidad, donde lo público abarca dos acepciones, en cierta forma, disyuntivas: lo social y lo político. A juicio de Arendt, en una cita rescatada por la investigadora argentina Leonor Arfuch:

Es justamente la emergencia de la sociedad en el mundo burgués, a la manera de una gran administración doméstica (housekeeping), con sus tareas, planificaciones y problemas, que sale desde el oscuro interior del hogar a la luz de la esfera pública, la que borra definitivamente la frontera clásica entre lo público y lo privado, desnaturalizando hasta lo irreconocible el significado de ambos términos. (2000, p. 7).

Si bien, en ese momento, no se distinguieron con fuerza las consecuencias de la irrupción de lo social (incluso Richard Sennett reparó en que la sociedad ilustrada logró mantener a ambos términos en "estado de equilibrio") hoy es posible afirmar que, desde entonces, la línea divisoria que separaba lo público y lo privado comenzó, indefectiblemente, a difuminarse. De ahí en adelante, empezamos a percibir -según Arendt- "el conjunto de pueblos y comunidades políticas a imagen de una familia cuyos asuntos cotidianos han de ser cuidados por una administración doméstica gigantesca y de alcance nacional" (Arendt, 1993, p. 42).

Con el ascenso de lo social, todas las materias que anteriormente pertenecían a la esfera privada (o familiar) involucraron un interés colectivo. Y, paralelamente, lo privado comenzó a configurarse y afianzarse, sobre todo, como una esfera de intimidad ${ }^{2}$-las pasiones del corazón, los pensamientos de la mente, las satisfacciones de los sentidos- que, con el auge del individualismo moderno, "perderá, incluso, su connotación de privación" (Arfuch, 2000, p. 8).

Ante este nuevo escenario, el modelo burgués -más allá de los reclamos de la civilidadentiende que lo público remitiría sobre todo al poder del Estado, retomando la idea griega

\footnotetext{
${ }^{2}$ Para Arendt, uno de los primeros teóricos de la intimidad fue Jean-Jacques Rousseau, quien llegó a su descubrimiento a través de una rebelión contra la insoportable perversión del corazón humano por parte de la sociedad, su intrusión en las zonas más íntimas que antes no habían necesitado protección. Y la intimidad del corazón -a desemejanza del hogar privado- no tiene lugar tangible en el mundo.

${ }^{3}$ En el sentido antiguo, el rasgo privativo de lo privado significaba, literalmente, el estado de hallarse desprovisto de algo, "incluso de las más elevadas y humanas capacidades" (Arendt, 1993:49). Sin embargo, hoy hemos dejado de pensar en términos de privación al referirnos a lo privado, situación que se explica, en parte, debido al enriquecimiento de la esfera privada a través del individualismo. Frente a este punto, Arendt agrega que, sin embargo, -y paradójicamente- esa esfera de intimidad sólo logrará materializarse exteriorizándose, desplegándose en lo público, fenómeno que tiene como principales protagonistas a los medios de comunicación.
} 
de unión entre política y la esfera de lo público. En este sentido, florece con fuerza el concepto de espacio público ${ }^{4}$ en tanto lugar discutidor y negociador, que les ofrece a las personas particulares -reunidas en los salones, cafés y clubes- la posibilidad de debatir el ejercicio del poder estatal.

La discursividad y reflexión propia de los griegos se desplaza ahora hacia este espacio público mediador. Así, el público ilustrado va abriendo espacios de sociabilidad para que los sujetos se sirvan de su propia razón y planteen sus opciones e ideas. El público es cada vez más conciente de su rol en la sociedad y del dominio que puede ejercer sobre ella (poder de la opinión pública). De esta manera, la publicidad se separa del poder estatal y se constituye como una tribuna de personas privadas reunidas como público, con capacidad de influir en lo público (el Estado).

A la luz de lo expuesto, saltan a la vista algunas coincidencias entre el modelo griego y el ilustrado. Pero también hay que destacar ciertos elementos que los diferencian. Principalmente, debemos tomar en cuenta que para formar parte del dominio público, los griegos exigían la pertenencia de bienes o tierras, requerimiento inexistente en el mundo moderno. El espacio público burgués, entonces, se nos presenta como un lugar "más democrático", al cual pueden acceder personas de diferente condición social ${ }^{5}$.

Por otra parte, observamos una clara diferencia en cuanto a función, pues para los modernos la formación de un espacio público "obedecía en principio al motivo moral de la emancipación" (Ferry, 1998, p. 16) -entendiendo que la sociedad civil se auto concebía como aquel grupo de personas que logra alcanzar la "mayoría de edad" ${ }_{-}$-, en tanto que, para los griegos, la constitución de este espacio habría estado fundada en "una estética de la figuración, de la autorepresentación, en que cada uno debe 'sobresalir' para conseguir la gloria gracias a las 'nobles palabras' pronunciadas en la plaza pública” (Ferry, 1998, p. 16).

El modelo ilustrado se impuso con fuerza hasta el advenimiento de las democracias masivas a principios del siglo XIX. No obstante, la industrialización, el desarrollo de la alfabetización, el auge de la prensa y la configuración de un Estado eminentemente administrativo, contribuyeron a su decadencia: los límites entre los ámbitos público y privado se tornaron cada vez más difusos y, como consecuencia, aquel público otrora

\footnotetext{
${ }^{4}$ En este sentido, cabe recalcar la ambigüedad con que Habermas nos presenta su idea de "espacio público". En primer lugar, el espacio público correspondería al lugar físico donde un "público" ilustrado se reúne a debatir sobre los asuntos del Estado, como por ejemplo, los cafés, salones, salas de redacción de prensa, etc. Por otro lado, hay que mencionar el rasgo virtual del "espacio público" en tanto lugar intangible, argumentativo y discursivo, ligado sobre todo a la escritura.

${ }^{5}$ En la época aludida, sin embargo, no existía aún un total universalismo en cuanto a las personas que podían ejercer su derecho a voto. Por ejemplo, en general se exigía la capacidad de leer y escribir, principio que considerando la estructura social de la época- se puede homologar a la posesión de bienes.

${ }^{6}$ El filósofo Inmanuel Kant plantea el concepto de mayoría de edad en su texto ¿Qué es la Ilustración? de 1784 .
} 
dedicado a debates políticos y culturales deviene en una multitud de consumidores. Así, la opinión pública deja progresivamente de ser producto de un discurso racional, a la vez que se instala la manipulación mediática como soporte principal de su configuración.

Desde entonces, el concepto de opinión pública cambia de sentido, pues ya no se trata de aquella de tipo ilustrada que se distinguía de una plebe inculta, sino que designa, más bien, "a la masa segmentada de opiniones particulares en las que se expresan intereses divididos y hasta conflictivos" (Ferry, 1998, p. 17).

De este modo, cabe aquí una redefinición del espacio público justificada por el advenimiento de la denominada sociedad de masas y, posteriormente, de la sociedad de los medios. Según Jean-Marc Ferry, el nuevo espacio público es, en sentido lato, "el marco mediático gracias al cual el dispositivo institucional y tecnológico propio de las sociedades postindustriales es capaz de presentar a un 'público ${ }^{77}$ los múltiples aspectos de la vida social" (Ferry, 1998, p. 19).

Pero además, en contraposición con los griegos, la política se ocupa cada vez más de la casa, la economía, la necesidad y la subsistencia, transformándose en un tema de administración. Así, se empiezan a confundir los conceptos de público y privado, pues la actividad privada adquiere un primordial interés público. Jean-Marc Ferry sostiene que:

Se escenifican públicamente aspectos de la vida que son a tal punto privados que los que forman el público se cuidarían mucho de abordarlos en el seno mismo de la esfera de la intimidad familiar (...) El espacio público supera hoy el umbral natural de lo que parece digno de comunicación. (1998, p. 21)

Sin duda, el fenómeno de imbricación entre ambas esferas afecta a todos los ámbitos del conocimiento pero, particularmente, -como profundizaremos a continuaciónreconfigura la teoría política. Lo cierto es que hoy advertimos cada vez con mayor fuerza un fenómeno que hemos denominado como "personalización" y "estetización" de la política, que alude a todos aquellos procesos mediante los cuales -en vez de una ideologíaprogresivamente se nos ofrecen personajes estéticamente atractivos. De este modo, se disuelve lo político en sus términos argumentativos y elementos como la vida privada, la dimensión subjetiva y el carisma adquieren un peso inusitado en la construcción de la imagen y la representación pública de los candidatos.

Es en este punto donde se puede advertir con claridad cómo la dimensión significante ha ido desplazando al significado (contemplando la doble articulación del signo

\footnotetext{
${ }^{7}$ Como subraya Jean-Marc Ferry, cabe reparar en que "el público del que se trata no está limitado en absoluto al cuerpo electoral de una Nación: más bien se trata de todos los que son capaces de percibir y comprender los mensajes difundidos en el mundo" (Ferry, 1998, p15).
} 
lingüístico): el poder abrumador de la imagen arrasa con la palabra y el acto de comunicación con la naturaleza de lo comunicado.

\section{La imagen es todo}

Como señalamos en los párrafos anteriores, en la segunda mitad del siglo XIX, la industrialización, el desarrollo de la alfabetización, el auge de la prensa y la configuración de un Estado eminentemente administrativo, contribuyeron a la decadencia del espacio público burgués, borrando la clara distinción entre los ámbitos público y privado, y transformando un público -antiguamente dedicado a debates políticos y culturales- en consumidores.

Así, la opinión pública ha dejado de ser producto de un discurso racional, a la vez que se instala la manipulación mediática como soporte principal de su configuración; y adquieren una predominancia especial disciplinas como la publicidad, las relaciones públicas y, sobre todo, la comunicación política ${ }^{8}$.

Ante estas transformaciones sociales y el evidente desarrollo de los medios de comunicación, la relevancia que antaño tenían aquellos lugares de intercambio de visiones entre los ciudadanos y quienes dirigen los estados, ha disminuido ostensiblemente. No obstante, es claro aún que la existencia de estos espacios es esencial a la hora de evaluar el grado de democracia alcanzado por una determinada nación.

Hoy, en las denominadas sociedades postindustriales ${ }^{9}$, han desaparecido aquellas nostálgicas figuras ilustradas como los cafés, los salones burgueses o las publicaciones literarias. Y este vacío ha sido llenado por un nuevo espacio público virtual: la televisión. Según Eliseo Verón:

La televisión se ha convertido en el sitio por excelencia de producción de acontecimientos que conciernen a la maquinaria estatal, a su administración, y muy especialmente uno de los mecanismos básicos del funcionamiento de la democracia: los procesos electorales, lugar en que se construye el vínculo entre el ciudadano y la ciudad. En otras palabras, ya estamos en la democracia audiovisual. (1998, p. 125)

\footnotetext{
${ }^{8}$ El sociólogo francés Dominique Wolton define la comunicación política como "el espacio en que se intercambian los discursos contradictorios de los tres actores que tienen legitimidad para expresarse públicamente sobre política, y que son los políticos, los periodistas y la opinión pública a través de los sondeos" (Wolton, 1998, p31).

${ }^{9}$ Según el filósofo argentino Eliseo Verón, las sociedades postindustriales "son sociedades en vías de mediatización, es decir, sociedades en que las prácticas sociales (modalidades de funcionamiento institucional, mecanismos de toma de decisión, hábitos de consumo, conductas más o menos ritualizadas, etc.) se transforman por el hecho de que hay medios" (Verón,1998, p124).
} 
De hecho, es en la televisión donde en la actualidad se dan los debates políticos, debates cada vez más exentos de significado y sentido, y cada vez más rebosantes de significantes y superficialidades. En otros términos, el poder abrumador de la imagen sobre la palabra, la primacía del acto de comunicación sobre la naturaleza de lo comunicado. Pero ¿̨por qué la televisión? ¿Qué elementos han hecho posible que se haya instalado cómo un actor político más y un nuevo espacio público?

Primero, habría que reconocer que el poder de la imagen es, a todas luces, abrumador. O, citando el dicho popular, "una imagen vale más que mil palabras". Un ejemplo que corrobora esta información es el que cita Michael Schudson, en su artículo “EEs Trucha o Hamburguesa?: Política y Telemitología”, que se basa en un anuncio de cuatro minutos y medio presentado por Lesly Stahl para la CBS durante la campaña presidencial de 1984 en Estados Unidos. El tema del aviso era el siguiente: el modo en que la Casa Blanca montaba eventos para Ronald Reagan y cómo manipulaba a la prensa, especialmente la televisión. Un tiempo después, Stahl confesó que un funcionario de la Casa Blanca la llamó apenas el anuncio salió al aire para decirle que le había encantado. "¿Cómo pudo gustarle?" le preguntó ella sorprendida. Y él respondió: “¿Cómo todavía no se ha dado usted cuenta? El público no presta atención de lo que usted dice, sólo miran las imágenes”. Desde este punto de vista, "Stahl comprendió que había montado, gratis, una película para la campaña republicana, un maravilloso montaje de escenas optimistas en las que siempre aparecía Ronald Reagan” (Schudson, 1997).

En segundo lugar, cabe destacar que luego del "fin de la Historia" ${ }^{10}$ y la caída de las utopías y de los andamiajes ideológicos, la forma de hacer política ha cambiado radicalmente. Más que en partidos o programas, a la hora de votar la ciudadanía ha optado crecientemente por tomar en cuenta aspectos como la personalidad y la forma de desenvolverse de los candidatos, características que pueden ser evidenciadas -más que de ninguna otra forma- a través de la televisión.

Hoy operan nuevas sensibilidades y formas de percepción al captar el mundo que nos rodea. Y estos cambios se relacionan, estrechamente, con la irrupción de la denominada cultura audiovisual o de la imagen: las tecnologías transformaron la existencia cotidiana, promoviendo la estetización del mundo. Pareciera ser que en la actualidad, nuestra relación con los discursos, con las formas de vida, con los programas éticos, con las teorías y los paradigmas críticos o científicos, está prefigurada por la experiencia estética. Hal Foster (citando a Frederic Jameson) precisa:

\footnotetext{
${ }^{10}$ Esta hipótesis es propia del politólogo norteamericano Francis Fukuyama y fue publicada por primera vez en un ensayo del mismo nombre, aparecido en la revista The National Interest (verano, 1988).
} 
Si en un principio la reificación liberó al signo de su referente, ahora, en un segundo momento, continúa su trabajo de disolución, penetrando en el interior del mismo signo y liberando al significante de lo significado, o del significado propiamente dicho. Este juego, ya no en el ámbito de los signos sino de los significantes puros o literales liberados del lastre de sus significados, sus significados anteriores, ahora genera una nueva clase de textualidad en todas las artes. (2001, p. 80)

Es decir, si la Modernidad se inaugura con un nuevo modo de significación que separa al signo del referente, la Posmodernidad se funda en aquella fuerza que desvincula el significante del significado" ${ }^{11}$. Como afirma el semiólogo chileno Álvaro Cuadra, "lo significado es puesto en entredicho (...) y nos quedamos con ese juego puro y aleatorio de significantes que llamamos Posmodernidad" (Cuadra, 2003, p. 71).

Como consecuencia del aislamiento del significante, esta especie de ontología posmoderna transforma la pregunta por el sentido en un sin sentido, pues sólo hay lo que se ve, "lo visible es lo real y verdadero" (Cuadra, 2003, p. 74). En opinión de Cuadra, hoy "asistimos a la muerte del signo como instancia de sentido; abolido el referente y el significado, sólo queda el brillo reluciente de los significantes multiplicados hasta lo infinito por las redes massmediáticas" (Cuadra, 2003, p.71).

Nos encontramos, entonces, frente a una revolución de la forma, donde brilla la silueta arquitectural de los signos sobre el telón de fondo del sin sentido. Y esto conlleva una serie de consecuencias prácticas que se resumen en la imposición de nuevas claves de lectura. En palabras de Álvaro Cuadra:

Las nuevas reglas constitutivas del habla social ya no remiten a los procesos de significación como sistema de reglas semánticas sino que se sostienen en la pura materialidad de su arquitectura. De este modo, el síndrome posmoderno resultaría ser una nueva clave de lectura, cuyo trayecto pragmático va de lo ideológico a lo estético. (Cuadra, 2003, p. 80)

La Posmodernidad, entonces, puede aparecer como un gigantesco proceso de pérdida de sentido, que ha conducido a la destrucción de todas las historias y referencias, haciendo que el individuo se vuelque hacia sí mismo. Así, se configura una sociedad invadida por el ámbito de lo privado, sobrepoblada de individuos narcisistas, sin grandes banderas ni ideologías, sumidos en "un presente que fluye incesante, lubricado por el deseo, en un éxtasis que excluye la memoria y la distancia crítica” (Cuadra, 2003, p. 81).

\footnotetext{
${ }^{11}$ Como consecuencia, "cuando la cultura se desplaza hacia los significantes, el ciudadano emplazado en convicciones cívicas que dan significado a su presencia se extingue e irrumpe el consumidor" (Cuadra, 2003, p. 75).
} 
Sin duda, los fenómenos descritos afectan directamente el terreno de lo público. Hoy, ante la inexistencia de ideologías políticas fuertes, la instauración de nuevas claves de lectura centradas en lo estético y la importancia que han ido adquiriendo los medios de comunicación (especialmente la televisión), las instituciones políticas han optado por especializarse progresivamente en ellos, a fin de desenvolverse con mayor soltura en sus cauces y aterrizar con más fuerza sobre la opinión pública.

Como consecuencia, surge una nueva forma de hacer política, orientada especialmente- a los medios de comunicación y, en particular, a la televisión. Asistimos, entonces, a un proceso que se puede denominar como "personalización" y "estatización" de la política ${ }^{12}$, es decir, en vez de una ideología, se nos ofrecen personajes estéticamente atractivos. Así, las personas se centran más en las figuras que en los programas que ofrecen o en las doctrinas que estas profesan.

De este modo, según Leonor Arfuch, se disuelve lo político en sus términos argumentativos, a la vez que el ascenso del ámbito privado y la tendencia al ensamblamiento de ambas esferas (pública y privada), hacen que elementos como la vida privada, la dimensión subjetiva y el carisma, adquieran un peso inusitado en la construcción de la imagen y la representación pública de los candidatos.

En esta misma línea, Richard Sennett subraya que, en nuestros tiempos, la sociedad sólo importa en la medida en que la veamos como un gran sistema psíquico pues, por ejemplo, "podemos entender que el trabajo de un político sea el de redactar una legislación determinada, pero ese trabajo no nos interesa hasta que percibamos el papel de la personalidad en la lucha política" (Sennett, 1978). En otras palabras, "un líder político candidato a un ministerio es considerado como confiable o auténtico según la clase de hombre que es, más que de acuerdo a las acciones o programas que defiende" (Sennett, 1978, p13).

Si a esto le sumamos -en la mayoría de los países- la ausencia de una institucionalidad política fuerte, la existencia de partidos "con poco perfil e influencia ideológica sobre la realidad, ante débiles lealtades partidarias y pocos votantes cautivos, se genera un espacio abierto en el que el poder del video se extiende con pocos contrapoderes a la vista" (Landi, 1991, p26).

En definitiva, la televisión logró adaptarse a estas nuevas circunstancias y se ha instalado como un ingrediente fundamental del escenario político, reconfigurándolo según sus

\footnotetext{
${ }^{12}$ Sin embargo, debe dejarse claro que no se trata de un proceso definido, sino de un acontecimiento en constante evolución, en el que cada día se buscan nuevas estrategias y formas de llegar al público. Por otra parte, este cambio en la forma de practicar la política será diferente en cada país, puesto que cada marco socio-cultural exigirá una morfología específica a los mensajes emitidos.
} 
reglas del espectáculo ${ }^{13}$ y potenciando, de este modo, la imagen del candidato, su personalidad y su historia personal, en desmedro de su programa e ideología política. El cambio es -a todas luces- radical, pues no sólo cambia la forma en que la política se transmite, sino también el modo en que se practica: es decir, se modifica desde dentro la política misma.

Por ejemplo, se comienza a categorizar -de antemano- quiénes podrían ser potenciales candidatos según calificativos como "televisable" o "no televisable". Como afirma Carolina Perelli, "aquellos que lleven la televisión en los huesos tienen mayores posibilidades que quienes no tienen el don de la comunicación” (Perelli, 1991, p. 167).

Los rostros de los candidatos llegan a transformarse en el mensaje mismo, al punto que los grandes afiches prescinden de toda leyenda. Sólo basta con la fotografía: resulta mucho más fácil juzgar al candidato y sus cualidades, que a su programa. Según Oscar Landi:

Desde la perspectiva del lenguaje, la televisión replantea la política en términos de imágenes, de esa combinación de significantes distintos en la que se jerarquiza lo no verbal: el cuerpo del político se torna altamente significante y activa en el televidente los modos de la lectura y descifre de la gestualidad. (1991, p. 30)

En una época en que se devaluó el género discursivo de la comunicación política y donde las palabras pierden credibilidad día tras día, el telespectador se transformó -en palabras de Landi- en un lector de indicios. Como "no quiere que le mientan más, el votante se va transformando en una especie de detective en busca - de modo indirecto- de señales de sinceridad, familiaridad cultural, honestidad del político" (Landi, 1991, p. 28).

Al respecto, Carlos Ossa señala que:

La visibilidad dada por la televisión hace de los gestos casi un género -en paradoja- sin narratividad, planos y ensambles, frases cortadas y cuerpos libreteados hablan de una expresión audiovisual que se fragmenta en el horizonte de un receptor acostumbrado a las múltiples ediciones y escasas referencias. La profusión de comentarios sin médula, análisis oscurecidos por el interés o miradas sin fisonomía, se unifican en la estetización de la coyuntura, o bien, en la confección de unos íconos políticos que buscan provocar la sensación de participación, mediante, el placer de mirar. (2004).

La videopolítica se puede entender, entonces, como el espacio por donde circulan los gestos y cuyo fondo es -esencialmente- escópico (deseo de ver sin acabar); "es la

\footnotetext{
${ }^{13}$ Para Raúl Bendezú Untiveros, "cuando en el ámbito de la comunicación mediática se habla de espectáculo se alude a la actividad que, a través de diferentes procedimientos sensoriales (lenguajes de expresión tecnológicamente organizados), intenta atraer y mantener la atención de la audiencia a través de recursos preferentemente visuales” (Bendezú, 1999, p191).
} 
exhibición de un momento tantas veces repetido que se olvida y vuelve camuflado a insistir en una variedad vacía: los gestos son la democracia de las superficies" (Ossa, 2004).

Esta primacía de la imagen hace cada vez más dificultosos los debates políticos profundos, a la vez que se rebajan la calidad de los mismos. A juicio de Oscar Landi:

Todo se vuelve más soft, ficcional y manipulable emocionalmente (...) La personalización que la cámara hace de la política es una forma de despolitización: no se puede comparar el valor de los indicios que encontramos en la cara del político con la dignidad de los programas partidarios. (1991, p. 32)

Las reglas del espectáculo y los elementos del entretenimiento reemplazan al debate público, y la política deviene en shows mediáticos donde los gobernantes deben recurrir a diversos dotes actorales con el afán de superar al adversario. Los candidatos, por ende, no sólo deben confrontarse con sus opositores políticos, sino que también con todos los demás protagonistas mediáticos. Tan preocupados de la forma, los políticos han perdido el dominio sobre los acontecimientos y buscan compensar esa pérdida de poder apelando al revuelo y la sobre-exposición. Hacerse notar, nunca pasar inadvertido. Esa es la consigna.

Como observamos, esta nueva forma de hacer política -que tiene como eje central la creciente adaptación a las reglas impuestas por los medios de comunicación- es otro de los rasgos distintivos de nuestra época. En este sentido, Marc Abélès hace una interesante comparación entre las formas predominantes de entender la política hoy, con respecto a etapas anteriores en las que el poder era inseparable de lo sagrado (como es el caso de las monarquías divinas) y donde los ritos (en tanto escenificación de la interferencia entre lo político y lo sagrado) adquirían una importancia primordial a la hora de mantener el "cosmos".

Según su opinión, uno de los rasgos que caracterizan las sociedades occidentales es la disociación del poder y lo sagrado, pues el espectáculo político superó a las manifestaciones clásicas que se referían a una trascendencia (Dios, la ley, etc.). A continuación, resumimos algunos aspectos comparativos expuestos por Abélès que permiten diferenciar nuestra época de aquella donde lo político y lo sagrado estaban fusionados:

- En primer lugar, cabe subrayar que cuando la comunicación adquiere un papel importante dentro del entramado político, lo que prima es la innovación: a falta de mensaje, hay que renovar continuamente su soporte. El rito, en cambio, siempre hace alusión a una tradición y, justamente, "cobra relieve por referencia explícita o implícita a la tradición" (Abélès, 1998, p. 141). 
- Otro rasgo destacable es la tendencia a acentuar intensamente la individualidad. Como afirmamos, "frente a su pantalla, el telespectador espera ver aparecer un rostro, está atento a una voz, a un tono: un buen líder es el que ha sabido crear esa 'diferencia' con ayuda de especialistas en comercialización y en audioimagen” (Abélès, 1998, p. 141). En el rito, en cambio, más que el oficiante, predomina un sistema de valores y símbolos que se ve reactualizado a través del acto ritual.

- Un último aspecto notable de la comunicación política moderna "es su carácter desterritorializado: un líder puede comunicar inmediatamente a la totalidad del planeta el mensaje de su elección; ya no hay necesidad de desplazar a las multitudes. Cada uno vive la política en su sillón" (Abélès, 1998, p. 141). Por el contrario, las prácticas rituales escenifican la dimensión de territorio.

Ya no caben dudas. El fenómeno de la videopolítica (o democracia audiovisual) ha venido para quedarse, y resultará difícil escapar a él. Esto se debe, en parte, según indica Oscar Landi a que:

La videopolítica parece posibilitar el desarrollo de partidos políticos de bajo tono ideológico, de agregación pragmática de reivindicaciones e intereses -lo que se conoce como catch all parties- ya sea por transformación de los preexistentes o por la emergencia de otros nuevos sobre la base de la confiabilidad despertada por ciertos líderes o estéticas políticas. (Landi, 1991, p. 27)

Sin partidos con sustentos ideológicos fuertes, la atención estará centrada, inevitablemente, en las personas. Por otra parte, y dado que la televisión provee información limitada, "verdaderos pantallazos de somera presentación de realidades complejas" (Perelli, 1991, p. 169), difícilmente se podrá inducir una reflexión clara en la audiencia. Así, se simplifican los temas y debates, y la atención se centra en rasgos "menos complejos" como la vida privada, la personalidad y la forma de desenvolverse de los políticos, cuestiones frente a las cuales todos se sienten con derecho a opinar, y ante las cuales todos parecen competentes.

Es decir, el vacío ideológico que sobrevino luego del Fin de la Historia, es potenciado por la televisión y sus reglas del juego. En palabras del psiquiatra argentino Jesús González Requena, el discurso televisivo dominante "tiende a vaciar el universo de ideologías, sistemas de valores, etc.: todo se convierte en $-\mathrm{y}$ es reducido a- espectáculo, valor de cambio visual, escópico" (González Requena, 1999, p. 132).

Y mientras la televisión siga alimentando una audiencia desinformada, el interés hacia los asuntos políticos seguirá disminuyendo. Pues, tal como una persona disfruta mucho más de una canción si ha sido educada para ello, así también "la información política se 
vuelve interesante si posee un juicio crítico de conocimiento político previo; entonces el flujo de las noticias se vuelve interesante, inteligible" (Sartori, 2003, p. 50).

Aquí se evidencia, entonces, la doble faz de la televisión pues, además de ser el lugar donde se escenifican los cambios, es en sí un eje reestructurador, un actor político que potencia estas transformaciones. La importancia que han adquirido los gestos, los cuerpos y los rostros -aspectos que paradójicamente operan a la vez en un terreno íntimo y exterior; personal y superficial- modifican desde dentro la política misma.

\section{La resurrección del populismo}

A pesar de que todas las características recién citadas parecen propias y exclusivas de nuestras sociedades actuales, muchos aseguran que el fenómeno de personalización y estetización de la política no remite a una manifestación totalmente nueva, sino que más bien estaríamos ante la reemergencia de antiguas formas de populismo, que primaron sobre todo en Latinoamérica- en la década del $30^{14}$.

Sin embargo, se trata de procesos distintos, y la base de esta distancia está, justamente, en la relevancia que han adquirido los medios audiovisuales como escenarios y ejes reestructurantes en el modo de hacer y entender la política. Carolina Perelli señala alguna de estas diferencias:

- En primer lugar, los antiguos líderes populistas combatían y subordinaban enérgicamente al poder empresarial. Hoy, en tanto, los nuevos caudillos se alían y apoyan en el empresariado, pues comprenden la importancia de operar al interior de una lógica de mercado.

- Por otro lado, los líderes populistas de antaño se basaban en la movilización de masas. Por el contrario, hoy adquiere una relevancia especial la acción mediática. Carolina Perelli sostiene que:

\footnotetext{
${ }^{14}$ El populismo en Latinoamérica tiene una historia propia. A finales del siglo XIX, se deteriora el modelo del Estado Liberal-Oligárquico caracterizado por el poder concentrado en elites aristocráticas, terratenientes y exportadoras de productos agrícolas. La exportación desató el crecimiento de centros urbanos, el desarrollo de industrias y la aparición de nuevos grupos sociales: los trabajadores industriales y los artesanos. Esto coincidió con la llegada de inmigrantes y refugiados europeos infundidos de ideas del socialismo y sindicalismo. En los años '30, la clase obrera latinoamericana -excluida de la participación política- ganó capacidades organizativas lo que coincidió con la aparición de los primeros líderes populistas. Estos líderes llegaron a unir las masas marginalizadas utilizando múltiples ideologías y sobre todo su carisma para movilizarles a romper con los convencionalismos del establishment. Sus discursos cargados de símbolos al pueblo y a la nación llevaron las masas a las calles apoyando el cambio de las elites.
} 
La relación entre el nuevo líder y los medios condiciona un nuevo estilo de acción, que no es el de la democracia cara a cara del antiguo caudillo con las masas en calles o plazas. Por eso, en estas nuevas formas de personalización del poder, el líder se dirige al votante, o el ciudadano en la intimidad de su hogar, alejado de sus interacciones sociales significativas. No se dirige a una clase sino a un individuo. (Perelli, 1991, p. 187)

Por esto, se usa un vocabulario simple, que llegue a todos y se apela a la emoción y al sentido común.

- Además, el actual líder político no se presenta como un semidiós por encima de la masa como lo hacían los populistas, sino como un hombre común, proveniente de la audiencia televisiva a la que se dirige. Esta dependencia de los medios de comunicación conlleva a que los nuevos caudillos generen adhesiones y odios "propios de una figura que hace apelaciones simbólicas, de tipo emocional y no programáticas” (Perelli, 1991:188), razón por la cual el cuidado de la imagen adquiere suprema importancia. Esto permite a los políticos convivir con los ídolos populares del deporte, el cine, la radio y la propia televisión.

- Por último, hay que recalcar que, a diferencia de los regímenes populistas, el nuevo caudillo no es apoyado por proponer un modelo social o económico diferente, sino que lo "único que ofrece como alternativa consistente es su propia persona. Su marca de autoridad emana de esa personalización” (Perelli, 1991, p188).

Rostros, cuerpos, gestos. La política se ha personalizado y estetizado. Y según algunos autores, este fenómeno no puede verse con buenos ojos pues implica, necesariamente, la degradación de aquellas formas "racionales, letradas e ilumnistas" en que se hacía política en el pasado.

A simple vista, el escenario descrito puede tener más desventajas que puntos a favor, sobre todo si se piensan los riesgos de manipulación que conlleva la videopolítica. Sin embargo, situarse en un escenario apocalíptico no parece ser la mejor alternativa. En este sentido, son muchos los investigadores que han procurado situar el fenómeno en su real dimensión, restringiendo la radicalidad de sus nefastas consecuencias.

Según la ensayista argentina Beatriz Sarlo, "no puede haber lugar para la nostalgia de pasadas (y probablemente hipotéticas) formas directas de política. Todo lo que puede hacerse es la crítica más radical de la videopolítica realmente existente" (Sarlo, 2004, p. 88).

De este modo, Sarlo expresa su disconformidad ante el actual sistema y propone que si bien no es posible imaginar la política sin televisión- es viable configurar cambios en la videopolítica. Después de todo, la política debe hacer visibles los problemas y mostrarlos en la escena pública para que se definan y encuentren solución, y una forma efectiva de hacerlo es -y será- a través de la pantalla chica. 
Es aquí donde Sarlo introduce una importante acotación: la política requiere a los medios como escenario de los problemas que ella misma ha identificado, pero no necesita inevitablemente de los animadores massmediáticos como mentores, porque si los asuntos "que son importantes para amplias mayorías se convierten en objeto solamente massmediático, el sentido de la política y de los políticos no aparecerá evidente para nadie" (Sarlo, 2004, p. 88).

Asimismo, Oscar Landi subraya:

El goce que el televidente experimenta al situarse en el lugar del poder visual frente a la pantalla, no impide su crítica y el ejercicio del aspecto activo, resignificante de lo que se emite (...) Un indicio de sinceridad o falsedad del político es tal sólo porque un receptor le atribuye ese carácter; para otro puede pasar inadvertido o querer decir otra cosa. (1991, p.32)

Además, la televisión no necesariamente potencia ${ }^{15}$, la imagen de un individuo pues, tal como repara Landi, "un abusivo uso de la televisión por políticos o periodistas poco creíbles puede terminar contaminándola de este atributo o produciendo fenómenos de saturación que alejan a la gente del medio" (Landi, 1991, p. 33).

Por esto, no debemos exagerar la importancia de la imagen. A la larga, la eficiencia política y la credibilidad de los partidos democráticos no se medirá, exclusivamente, en función del "ruido mediático" que son capaces de generar, sino por su capacidad de transmitir una propuesta convincente a través de los medios y por fuera de los mismos. Considerando que la política aún insiste en su estirpe ilustrada, en la actualidad no es posible la estructuración de una campaña sin un mínimo de contenido. Si bien los procesos de creación de sentido son inseparables de la cultura mediática; esta premisa, antes que paralizadora, debe estimular -sobre todo a la teoría de la comunicación- la búsqueda de diversas fórmulas que permitan que este espacio mediático sea lo más democrático posible.

Antes que demonizar la existencia de los medios masivos, habría que centrarse en el estudio de sus potencialidades. Por ejemplo, son muchos los aportes en cuanto a la democratización del espacio público, pues antes sólo un escaso número de lectores podía acceder a aquellas discusiones donde se debatían asuntos de interés general. Hoy, en cambio, ese tipo de información está al alcance de un número cada vez más amplio de personas.

\footnotetext{
${ }^{15}$ Esto porque, en opinión de Landi, "la espectacularización televisiva de la política también paga los costos y comparte la incertidumbre de todo espectáculo: siempre hay un plus no controlable, una cuota de azar decisiva, una reacción del espectador no previsible. La magia del espectáculo es un terreno resbaladizo con una cuota importante de apuesta" (Landi, 1991, p. 33).
} 
Ciertamente, un verdadero público debe tener como base la interacción discursiva de los ciudadanos y, en este sentido, "tal vez haya que considerar el concepto de audiencia como una etapa, una etapa modesta, por cierto, pero necesaria hacia la constitución de ese público" (Dahlgren, 1997, p. 263), pues participar en una audiencia podría desembocar en pertenecer a un público.

Esta mirada más optimista, es compartida también por Dominique Wolton, quien plantea que criticar la política por ajustarse a esta realidad, y hasta reclamar un cambio de actitud, significa ignorar la existencia de una moderna sociedad de medios. En opinión de Wolton, "la comunicación política exactamente se nos revela como lo contrario de una degradación de la política y como la condición del funcionamiento de nuestro espacio público ensanchado" (Wolton, 1998, p. 31), pues permite la interacción entre la información, la política y la comunicación. De este modo, "no lleva a suprimir la política o a subordinarla a la comunicación sino, por el contrario, a hacerla posible en la democracia masiva" (Wolton, 1998, p. 31).

En tanto, Eliseo Verón comparte la visión de Wolton e, incluso, afirma que el tan citado empobrecimiento del discurso político no se debe a la irrupción de lo audiovisual. A su juicio:

El ingreso de lo político en la era audiovisual ha significado, por el contrario, un enriquecimiento de la discursividad política, mediante la incorporación de nuevos registros de sentido (en especial, el de lo indicial), y mediante la complejizaición de las estrategias que de ella resultan. (1998, p. 138)

En el caso del espacio público -como recalca Dahlgren- se trata de no abandonar el concepto a una especie de referente descriptivo, sino de "permanecer atento a lo que el espacio público podría ser o debería ser” (Dahlgren, 1997, p. 253), para así trazar nuevas líneas divisorias que nos acerquen cada vez más a la construcción de una sociedad democrática.

\section{Referencias bibliográficas}

Abélès, Marc. (1998). Rituales y Comunicación Política Moderna. En El Nuevo Espacio Público. España: Gedisa.

Arendt, Hannah. (1993). La Condición Humana. España: Paidós.

Arfuch, Leonor. (2000, noviembre). Lo Público y lo Privado en la Escena Contemporánea: Política y Subjetividad. Revista de Critica Cultural. $N^{\circ} 21$.

-- (2002). El Espacio Biográfico. Dilemas de la Subjetividad Contemporánea. Argentina: Fondo de Cultura Económica. 
Bendezú Untiveros, Raúl. (1999). La Espectacularización Mediática. En La Pantalla Delirante. Chile: Ediciones Lom-Arcis.

Cuadra, Álvaro. (2003). De la Ciudad Letrada a la Ciudad Virtual. Chile: LOM Ediciones.

Dahlgren, Peter. (1997). El Espacio Público y los Medios. ¿Una Nueva Era? En Espacios Públicos en Imágenes. España: Gedisa.

Ferry, Jean-Marc. (1998). Las Transformaciones de la Publicidad Política. En El Nuevo Espacio Público. España: Gedisa.

Foster, Hal. (2001). El Retorno de lo Real: La Vanguardia a Finales de Siglo. España: Ediciones Akal.

González Requena, Jesús. (1999). El Discurso Televisivo. Espectáculo de la Posmodernidad. España: Ediciones Cátedra.

Habermas, Jürgen. (1981). Historia y Crítica de la Opinión Pública. La Transformación de la Vida Pública. España: Editorial Gustavo Gili.

Jameson, Frederic. (1988). Posmodernismo y Sociedad de Consumo. En La Posmodernidad. México: Editorial Colofón.

Landi, Oscar. (1991). Videopolítica y Cultura. Revista Diálogos de la Comunicación (FELAFACS). № 29.

Mehl, Dominique. (1997). La Vida Pública Privada. En Espacios Públicos en Imágenes. España: Gedisa.

Ossa, Carlos. (2000, noviembre). La Trama Estallada (Televisión y Espacio Público). Revista de Crítica Cultural. $\mathrm{N}^{\circ} 21$.

------- (2004). La Vitrina Vacía. Temuco (Chile): Seminario Nacional El Derecho a la Comunicación. Medios y Demandas Ciudadanas, Universidad Mayor, 1-3 de septiembre.

Perelli, Carolina. (1991). La Personalización de la Política. Nuevos Caudillos, Outsiders, Política Mediática y Política Informal. En Partidos y Clase Política en América Latina en los 90. Costa Rica: Instituto Interamericano de Derechos Humanos.

Sarlo, Beatriz. (2004). Escenas de la Vida Posmoderna. Intelectuales, Arte y Videocultura en la Argentina. Argentina: Seix Barral.

Sartori, Giovanni. (1998). Homo Videns. La Sociedad Teledirigida. España: Ediciones Taurus.

------- (2003). Videopolítica. Medios, Información y Democracia de Sondeo. México: Fondo de Cultura Económica.

Sennett, Richard. (1978). El Declive del Hombre Público. España: Ediciones Península.

Schudson, Michael. (1997). ¿Es Trucha o Hamburguesa?: Política y Telemitología. En Espacios Públicos en Imágenes. España: Gedisa.

Verón, Eliseo. (1996). La Semiosis Social. España: Gedisa.

-- (1998). Interfaces. Sobre la Democracia Audiovisual Evolucionada. En El Nuevo Espacio Público. España: Gedisa.

Wolton, Dominique. (1998). "La Comunicación Política: Construcción de un Modelo. En El Nuevo Espacio Público. España: Gedisa. 